\title{
柱梁接合部の脆性破断評価に抢ける縮小試験体使用の課題
}

脆性破壊特性に及ぼす幾何学寸法効果

\section{ISSUES IN USING REDUCED-SIZE SPECIMEN FOR BRITTLE FRACTURE EVALUATION OF BEAM-TO- COLUMN STEEL CONNECTIONS}

Geometric size effect on brittle fracture properties

\author{
大家直也 ${ }^{* 1}$, 川畑友弥 ${ }^{* 2}$, 吉敷祥 一 ${ }^{* 3}$, 中込忠男*4 \\ Naoya OIE, Tomoya KAWABATA, Shoichi KISHIKI \\ and Tadao NAKAGOMI
}

\begin{abstract}
The authors evaluate the effect of size on the brittle fracture initiation properties using proportionally sized specimens with 4:2:1 geometry, with the aim of clarifying the relationship between geometric shape (size) and brittle fracture properties. Three-point bending tests are conducted on eight types of specimens with different sizes and notch depths. Interpretations using simple beam theory or the traditional fracture mechanics parameter, crack tip opening displacement (CTOD) shows a large scale dependence. It is evident that an appropriately improved local approach is proposed to interpret the experimental results.
\end{abstract}

Keywords: brittle fracture, geometric size, local approach, weibull stress, FEM analysis 脆性破壊, 幾何学寸法, ローカルアプローチ, ワイブル応, 有限要素法解析

\section{1. 序論}

\section{1 背景}

鋼構造建築物の梁端接合部における最終的な破壊モードとして, 局部座屈と破断が考えられる，破断のうち，脆性破壊は接合部の応 力伝達の大部分を失わせるため, 必ず回避しなければならない破壊 現象である。しかし，部材が板厚の薄い鋼材で製作されれば，破壊 よりも早く局部座屈が発生するため, 特に兵庫県南部地震以前では 破断を大きな問題とは考えていなかった. 建築物の層数やサイズが 大きくなるにつれて, 使用寸る部材の厚さも増しており, 極大地震 が起きた際には脆性破壞が発生し易くなっているものと考えられる. 脆性破壊を含めた耐破壊性能を評価寸るためには実大の構造物を用 いた破壊実験を行うのが直接的であるが，実際には実大の構造物を 実験することは困難であり, 縮小された試験体で性能評価を行う状 況が今後も予想される。

脆性破壊は圧力容器や船舶など他の構造物において顕在化した問 題である.それら構造物の多くの破壊事故を経て第二次世界大戦後,
破壊力学という学術分野が確立された。破壊力学の目的は材料試験 体等の縮小試験体で構造物の耐破壊性能を評価することであり，規 格などを通じて標準的な評価システムが既に確立されている ${ }^{1,2)}$. ま た, 破壊力学を用いた性能評価においては, 溶接部に不可避的に存 在する欠陥からき裂が発生・伝播し脆性破壊に至るということを想 定している.しかし，鋼構造建築物における一般的な梁端接合部で は，溶接部に小さな欠陥があっても，梁フランジのスカラップ底部 を起点とした母材の脆性破壊，あるいは同位置において延性亀裂の 進展の後に脆性破壊に移行することの危険性が溶接部の脆性破壊発 生可能性を上回る $\left.{ }^{3,4}\right)$ ため, 性能評価試験を行う場合, 溶接部に久陥 を想定しないことが多い。したがって，上記の性能評価試験の前提 条件, 寸なわち脆性破壞の発生起点を欠陥としているか否かの違い から, 鋼構造建築物には他の分野と比べると破壊力学の知見があま り適用されてこなかったものと考えられる，そのため，試験体寸法 の性能評価結果一の影響を排除できる方法を，鋼構造建築の分野で も検討していく必要がある.

\footnotetext{
*1 東京大学大学院工学系研究科システム創成学専攻 大学院生・学士 (工学)

*2 東京大学大学院工学系研究科システム創成学専攻 教授. 工博

*3 東京工業大学科学技術創成研究院未来産業技術研究所 教授 - 博士 (工学)

*4 信州大学工学部建築学科 特任教授. 工博
}

Grad. Student, Dept. of Systems Innovation, Faculty of Engineering, the University of Tokyo, B.Eng.

Prof., Dept. of Systems Innovation, Faculty of Engineering, the University of Tokyo, Dr.Eng

Prof., Laboratory for Future Interdisciplinary Research of Science and Technology, Institute of Innovative Research, Tokyo Institute of Technology, Dr.Eng

Specially Appointed Prof., Dept. of Architecture, Faculty of Engineering. Shinshu University, Dr.Eng. 


\section{2 既往研究}

2018 年度に著者らは Fig. 1 に示す 4:2:1（それぞれ L サイズ，M サイズ， $\mathrm{S}$ サイズ）の 3 段階にスケーリングした溶接組立 $\mathrm{H}$ 形断面 の柱梁溶接接合部に対して 3 点曲げによる繰り返し載荷実験を行っ た注 1). 脆性破壊を終局状態とする地震時吸収エネルギー評価指標で ある骨格曲線における等価累積塑性変形倍率 $\mathrm{E} \eta \mathrm{S}$ を使用材料 3 サイ ズの勒性レベルが $\mathrm{M}$ サイズ, $\mathrm{S}$ サイズの勒性と同じになるよう補正 し，それぞれ補正した結果を Fig. 2 に示す. サイズを大きくするこ とにより性能が低下寸る, いわゆる寸法効果が見られることが分か った注 2). また, 同実験の破面観察結果例を Fig. 3 に示す注2)。す心゙ ての試験結果において延性き裂が先行し, サイズの大きなものほど 同じサイクルでも大きな延性き裂に進展することが分かった，延性 き裂の進展は大きな欠陥生成になるため, 延性き裂が進展するほど 脆性破壊が促進される一つの要素になると考えられる.

\section{3 研究目的}

1.2 節で述べたように，柱梁接合部全体としての耐破壊特性には 延性破壞特性と脆性破壊特性が含まれる。さらには，溶接部残留応 力分布や溶接変形なども試験体の寸法によって結果への影響度が異 なる可能性もあり, 構造実験の結果のみからその構成要素や寄与割 合を解明するのは簡単ではない. 本研究では幾何学的条件 (サイズ) と脆性破壊特性の関係のみを純粋に取り出すことを目的とし, 構造 実験と同様, $4: 2: 1$ の形状を持つ等比試験片を用いて, 脆性破壊特性 に及ぼす寸法効果を評価する。 また, 最新の破壊力学を用いた破壊 評価指標を用いることにより脆性破壊特性を統一的に評価可能であ るかを検証する。

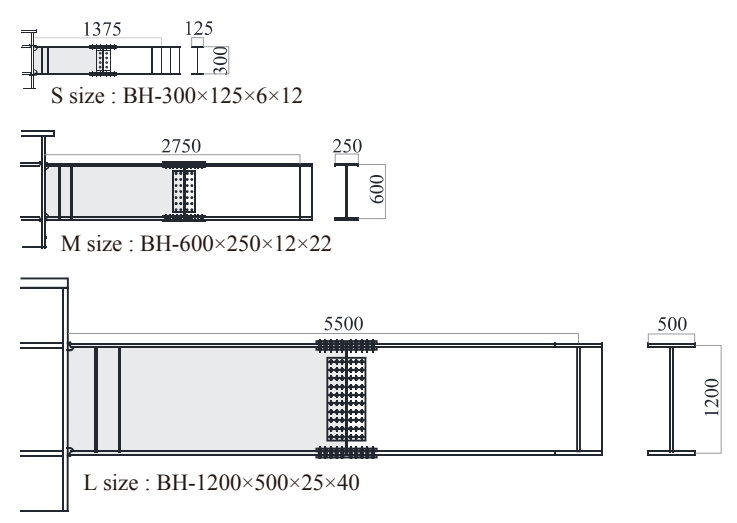

Fig. 1 Comparison of size of each specimen 注 1)

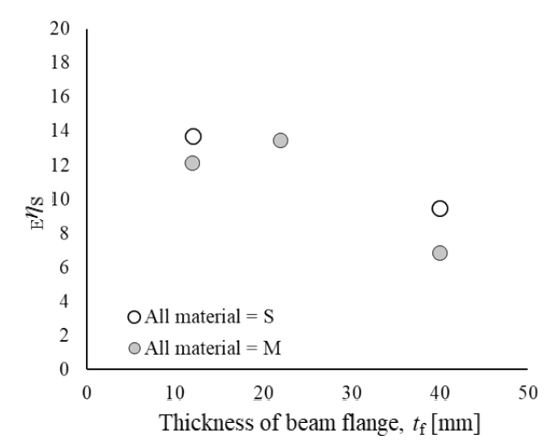

Fig. 2 Scale effect by normalized equivalent cumulative plastic deformation 注 2 )

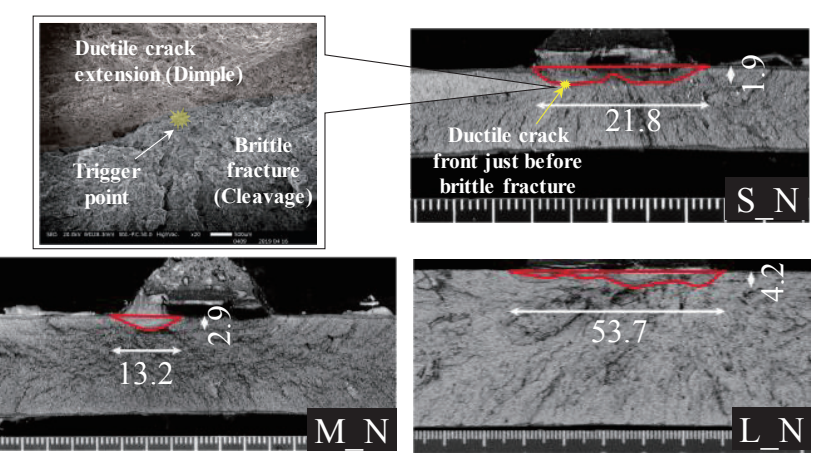

Fig. 3 Fracture appearance and SEM observation for brittle fracture initiation site (mark S_N) 注 2)

\section{2. 実験}

本研究では 1.1 節に示した通り，脆性破壊特性に及ぼす純粋な幾 何学的条件の影響を調查する目的で，柱梁溶接接合部に用いたもの と同種の鋼材を用い，異なる試験片寸法・切欠きの長さを持つ 8 種 類の試験片について三点曲げ試験を行った．本章では三点曲げ試験 結果に基づき古典的な評価手法で評価した結果を整理する。まず, それらの破壊限界条件の評価を切欠きがない梁部材と見立てて, 材 料力学の知見から各試験片の限界荷重を板厚で正規化して行った. 次に代表的な破壊力学パラメータの 1 つである CTOD（Crack Tip Opening Displacement: き裂先端開口変位）も用いて材料の破壞勒 性の評価を行った。ただし，この試験片は確実に等比形状とするた めに疲労き裂の代わりに鋭い切欠きを設けており，国際規格で規定 されている CTOD 試験 5により導出された CTOD と呼ぶことはで きないため, 切欠きをき裂と見立てて同様に評価することで算出し， これを疑似的という意味を込めて quasi-CTOD $\left(\delta_{\text {quasi }}\right)$ と呼ぶこと とした。

\section{1 供試材}

使用する鋼板は板厚 $40 \mathrm{~mm}$ の SN490B を原板とした. 鋼板に含 まれている化学成分を Table 1 に示寸.鋼材は, 二相域焼入れ $\left(750^{\circ} \mathrm{C}\right)$ 一焼戻し $\left(300^{\circ} \mathrm{C}\right)$ 処理による調質を行った後に試験に供している. $0^{\circ} \mathrm{C}$ においてシャルピー試験を試験片数 6 で実施したところ，シ ヤルピー吸収エネルギーの平均值は $v E_{0}=19.5 \mathrm{~J}$ と得られた。 なお シャルピー試験片は，板厚 $\mathrm{t}$ について板厚方向における $\mathrm{t} / 2$ の部分 から，試験片の長手方向が圧延方向（L 方向）に，Vノッチの方向 が圧延直角方向（C 方向）になるように採取している。また，室温 における丸棒引張試験結果を Fig. 4 に示す. 二相域熱処理のため, 降伏比が小さくなっている. 引張試験片は, 板厚方向における $\mathrm{t} / 4$ の 部分から，C方向に採取している. 引張試験の採取位置, 採取方向 は 2.2 節で後述する三点曲げ試験とは異なっているが，熱処理の調 質により機械特性が等方的かつ均一に分布していると考え，三点曲 げ試験片も Fig.4 と同様の機械特性を持つと判断した.

Table 1 Chemical composition of test steels mass [\%]

\begin{tabular}{c|c|c|c|c|c|c|c|c}
\hline $\mathrm{C}$ & $\mathrm{Si}$ & $\mathrm{Mn}$ & $\mathrm{P}$ & $\mathrm{S}$ & $\mathrm{Cu}$ & $\mathrm{Mo}$ & $\mathrm{Nb}$ & $\mathrm{V}$ \\
\hline 0.13 & 0.23 & 1.30 & 0.012 & 0.006 & 0.14 & 0.07 & 0.012 & 0.005 \\
\hline
\end{tabular}




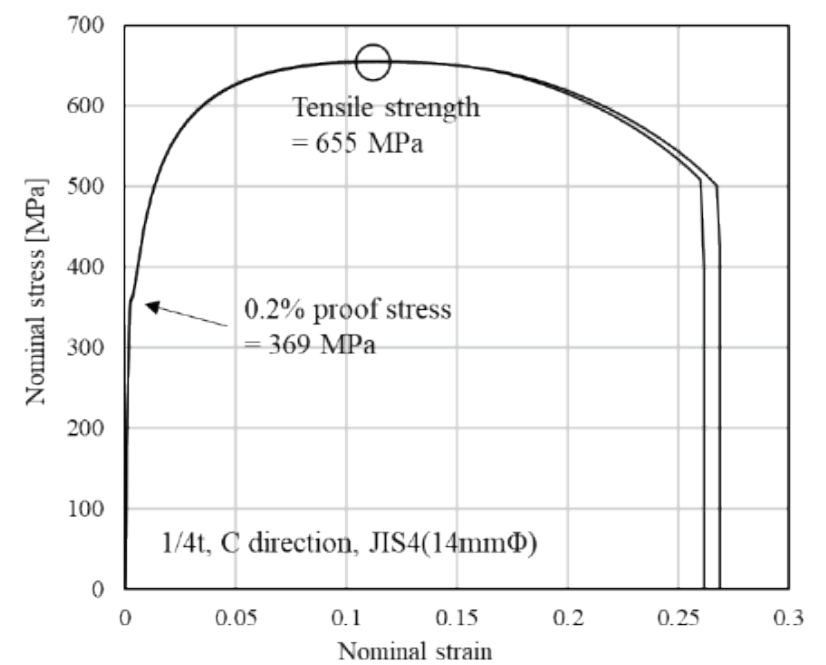

Fig. 4 Tensile test results at ambient temperature

\section{2 三点曲げ試験}

三点曲げ試験片はいずれの試験片も板厚方向における $\mathrm{t} / 2$ の部分 から，L方向に採取している. 試験片の外形は CTOD 試験規格 5)に 従い, 全ての試験片で幅 $(W)$ が板厚 $(B)$ の 2 倍, スパンの長さ $(S)$ が幅の 4 倍となるように設定した. 切り欠き長さ $\left(a_{0}\right)$ は幅の $1 / 2$ とした. き裂として各条件での試験片数は 5 とし, 合計 40 本の 試験片を準備した. 8 種類の試験片それぞれの試験寸法や切欠き長 さ条件を Table 2 に示寸.ここで Table 2 において $B$ は試験片の板 厚 $[\mathrm{mm}], W$ は試験片の幅 $[\mathrm{mm}], L$ は試験片の全長 $[\mathrm{mm}], \mathrm{S}$ は 試験片の三点曲げ試験の際のスパン長さ $[\mathrm{mm}], a_{0}$ は試験片の初期 の切久き長さ $[\mathrm{mm}]$ である. 8 種類それぞれの試験片の図と切欠き 部の拡大図を Fig. 5 (次頁) に示寸. 幅 $(W)$, 板厚 $(B)$, スパンの 長さ $(S)$, 試験片の全長 $(L)$ がそれぞれ試験片のどの寸法を指して いるかは, CTOD 試験規格 5)に準じており, Fig. 5 の Mark(1)の試 験片に例示してある. 切欠き先端の曲率半径については極力鋭いも のを導入することを目指し, 8 種類の試験片に共通して $R=0.25 \mathrm{~mm}$ となるようにした。(1)(2)(3)切欠き長さ比 0.5 における $1,1 / 2,1 / 4$ サイズ, (4)(5)(6)は切欠き長さ比 0.1 における $1,1 / 2,1 / 4$ サイズ, (7)(8)(3)は切欠き長さを $10 \mathrm{~mm}$ に固定し外形のみ $1,1 / 2,1 / 4$ サイズ として結果を比較する.

Table 2 Configurational conditions of test specimens

\begin{tabular}{c|c|c|c:c:c:c}
\hline Mark & $\begin{array}{c}B \\
{[\mathrm{~mm}]}\end{array}$ & $\begin{array}{c}W \\
{[\mathrm{~mm}]}\end{array}$ & $\begin{array}{c}L \\
{[\mathrm{~mm}]}\end{array}$ & $\begin{array}{c}S \\
{[\mathrm{~mm}]}\end{array}$ & $\begin{array}{c}a_{0} \\
{[\mathrm{~mm}]}\end{array}$ & $a_{0} / W$ \\
\hline$(1)$ & 40 & 80 & 340 & 320 & 40 & 0.5 \\
\hline (2) & 20 & 40 & 180 & 160 & 20 & 0.5 \\
\hline (3) & 10 & 20 & 100 & 80 & 10 & 0.5 \\
\hline (4) & 40 & 80 & 340 & 320 & 8 & 0.1 \\
\hline (5) & 20 & 40 & 180 & 160 & 4 & 0.1 \\
\hline (6) & 10 & 20 & 100 & 80 & 2 & 0.1 \\
\hline (7) & 40 & 80 & 340 & 320 & 10 & 0.125 \\
\hline (8) & 20 & 40 & 180 & 160 & 10 & 0.25 \\
\hline
\end{tabular}

全ての試験片について $-60^{\circ} \mathrm{C}$ 下で三点曲げ試験を行った。試験温 度は全ての試験片において切り欠き先端から延性き裂が生じない温 度として選定した。温度調整はステンレスで製作した泠却槽中のア ルコールに液体窒素，ドライアイスを静かに投入することにより行 い, 試験実施中には常に $3^{\circ} \mathrm{C}$ の温度範囲に制御した. 試験は $500 \mathrm{kN}$ 油圧式万能試験機を用い，ジグを介して試験片に曲げ荷重を付与し た．試験機のロードセル荷重およびクリップゲージを介して常時測 定した切り欠き開口変位を試験結果として記録した。試験結果を Fig. 6 （次頁）に示寸．図の縦軸はロードセル荷重 $P[\mathrm{kN}]$, 横軸は クリップゲージ開口変位 $V_{\mathrm{g}}[\mathrm{mm}]$ を示している.いずれの条件にお いても試験片は一回の脆性破壞でほとんど全ての荷重が解放された。 また，三点曲げ試験における脆性破壊後の試験片の破面について， 肉眼スケールの写真の一例を Fig. 7 に, 走査型電子顕微鏡(SEM: Scanning Electron Microscope)による観察画像の一例を Fig. 8 に 示寸. Fig.8 では左右の 50 倍, 1000 倍の観察画像どちらにおいて も脆性破壞発生起点と推定される場所を丸印で囲っている．破面観 察においても脆性破壊発生に先行する延性き裂は認められず，本試 験は鋼材の破壊において脆性破壊のみを取り出すことができている と考えられた。

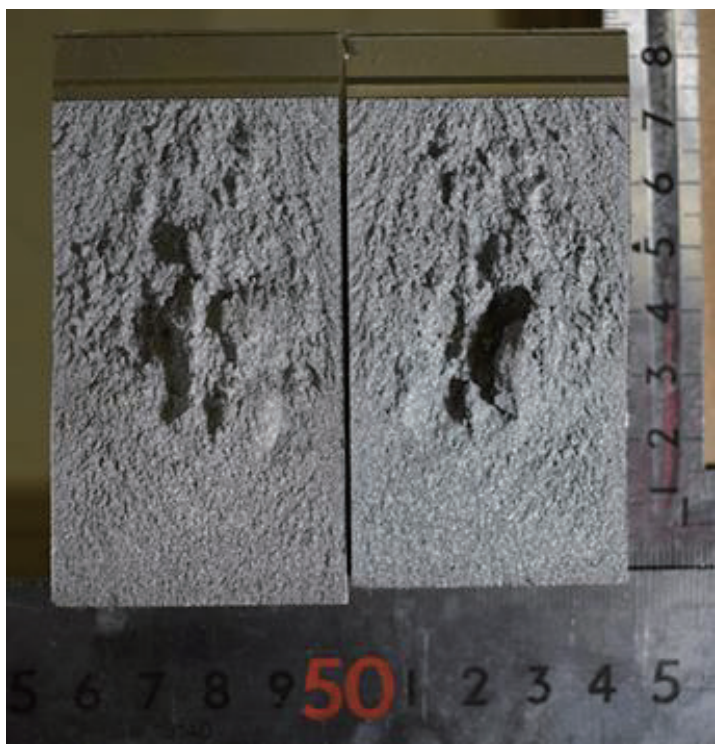

Fig. 7 Fracture surface in this three-point bending tests (sample number (7)-5)

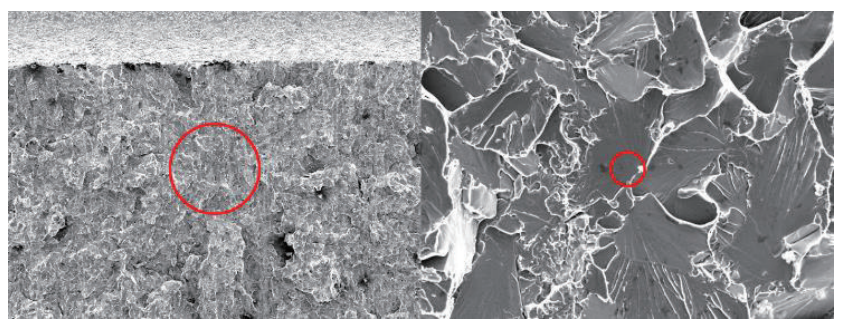

Fig. 8 Observation image around brittle fracture initiation point on SEM (sample number (3)-3) 


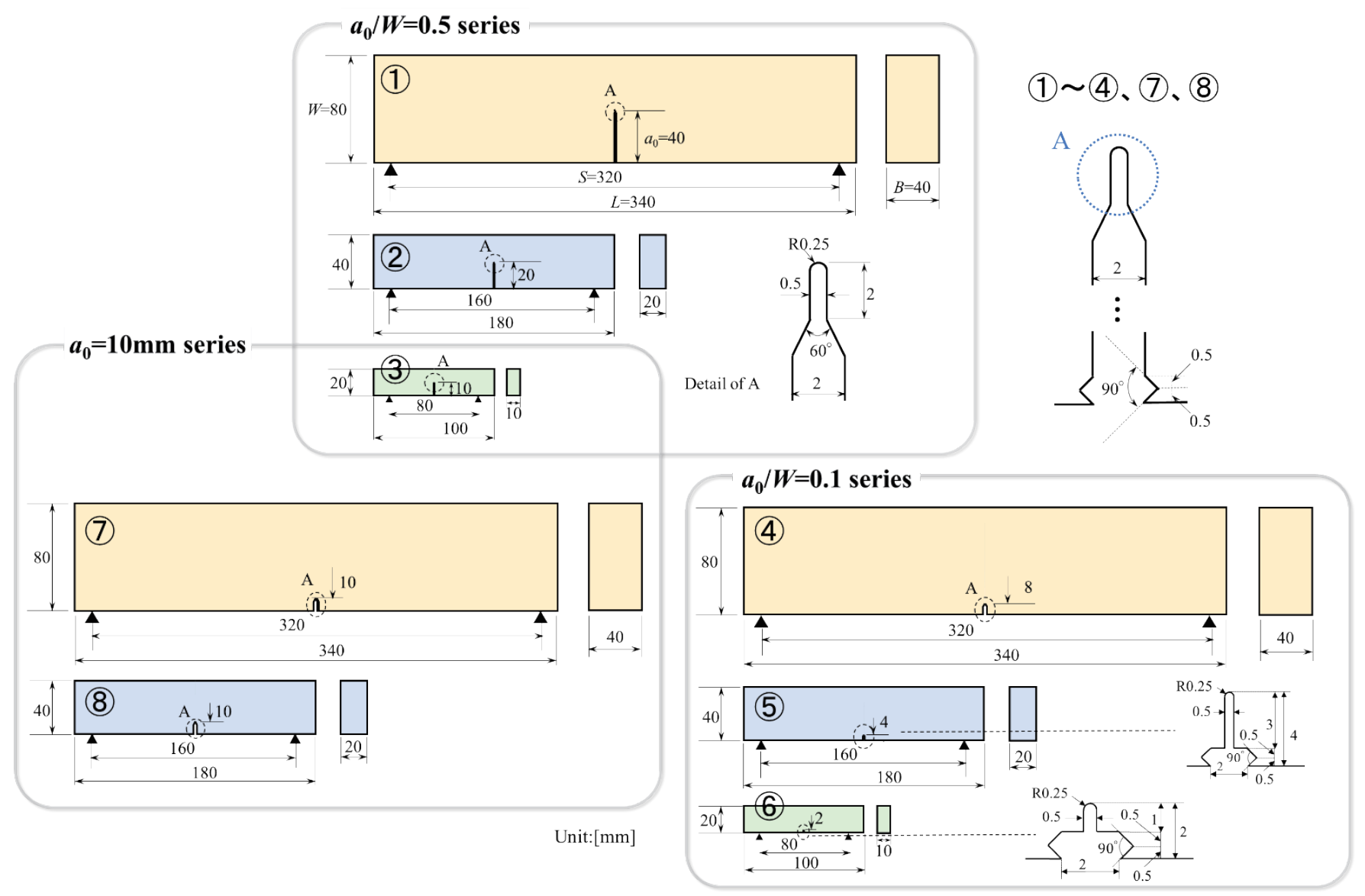

Fig. 5 Specimen configuration and its design concept
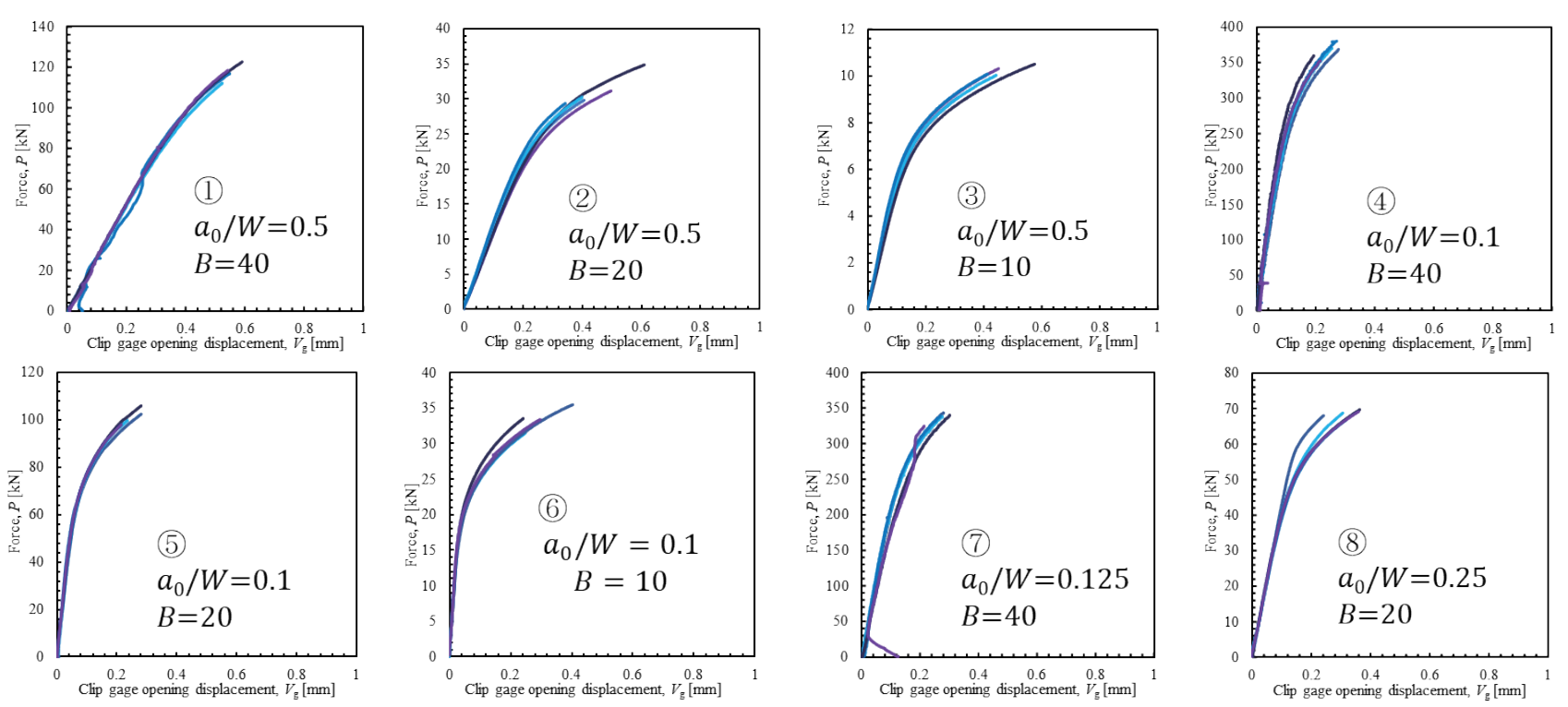

Fig. 6 Force - Clip gage displacement curves of three-point bending tests at $-60^{\circ} \mathrm{C}$

\section{3 材料力学的視点による曲げ応力指標を用いた整理}

2.2 節の試験結果を, 試験片を材料力学的な視点で単純な梁部材 であると仮定し, 限界曲げ応力の考えに基づき各試験片の板厚によ って正規化された限界荷重として整理した。しかし実際に行った三 点曲げ試験片のまま計算を行うと, 切欠きの存在により試験片を単
純な梁部材とみなすのは難しい. 試験片の切欠き先端には切欠き効 果として当然応力集中がもたらされる.ここでは単純化のため, 切 久き先端曲率半径が等しいことを考慮に入れ，Fig. 9 に示すように 切欠きが無い梁部材と見立てて実験結果の整理を行った. Fig.9 で は幅に対する切欠きの長さ比 $\left(a_{0} / W\right)=0.5$ の試験片を例示してある. 
切欠きは板厚を貫通しているためリガメント部のみを梁部材の有効 体積とし, リガメント部における幅を有効幅 $h$ とした.

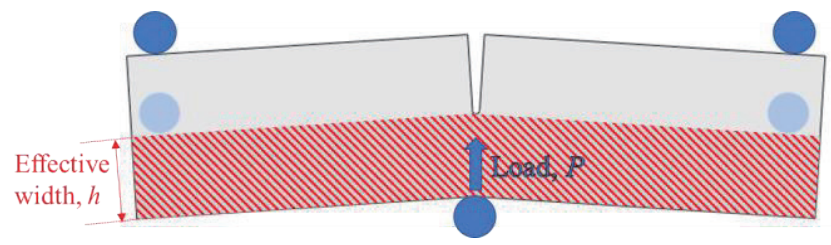

Fig. 9 View in calculation based on mechanics of materials

試験片の板厚によって正規化された限界荷重を導出する際の仮定 を示す. 試験片中央部における最大曲げ応力はモーメントと梁形状 に固有の断面二次モーメントを考慮することにより式(1)のように 得られる.ここで, 曲げ応力が限界条件を規定するパラメータであ るとし, 式(1)を荷重について整理すれば, 限界荷重 $P_{\mathrm{cr}}$ は式(2)にて表 せる.

本研究で用いた三点曲げ試験片における幾何学形状の制約条件 $W=2 B, S=4 W$ および $h=W-a_{0}$ であることを用いれば，式(2)は 式(3)のように整理できる. 限界曲げ応力 $\sigma_{\mathrm{cr}}$ が材料定数であるとすれ ば，式(4)の左辺は試験片形状に拠らず一定值となると考えられる.

$$
\begin{gathered}
\sigma_{\mathrm{max}}=\frac{3 P S}{2 B h^{2}} \\
P_{\mathrm{cr}}=\frac{2 B h^{2}}{3 S} \sigma_{\mathrm{cr}} \\
P_{\mathrm{cr}}=\frac{1}{12}\left(2 B-a_{0}\right)^{2} \sigma_{\mathrm{cr}} \\
\frac{12 P_{\mathrm{cr}}}{\left(2 B-a_{0}\right)^{2}}=\sigma_{\mathrm{cr}}=\text { constant }
\end{gathered}
$$

式(4)の左辺を有効破壞荷重（単位次元は応力と同じ $\mathrm{Pa}$ とした） とし形状に拠らない材料固有の定数として材料破壊時の指標に用い, 8 種類 $\times 5$ 本で合計 40 本の試験片に対して評価を行った. 評価結果 を Fig. 10 に示す. 図の縦軸は先ほど定義した有効破壊荷重 [MPa], 横軸は試験片の板厚 $B[\mathrm{~mm}]$ を示している. 試験結果は同じ板厚, 同じ切久き長さ比を持つ同形状の試験片の中でも, 有効破壊荷重に は若干のばらつきがあるが，これは脆性破壊という現象が最弱リン ク説 8)に基づく確率事象であることを考慮すれば当然の結果である. Fig. 10 ではばらつきの範囲をエラーバーで, 平均値をプロットで示 す. 結果を見ると, 同じ $a_{0} / W$ 条件であっても板厚増加により有効 破壊荷重は明確に減少しており, 統一した整理が難しいことが分か る.これはいわゆる寸法効果の影響を受けていると解釈できるもの である. 同じ板厚条件内での $a_{0} / W$ の影響については, ほぼ統一的 に整理できるようである. しかし, 本試験片の形状では $a_{0}$ (切欠き 長さの絶対值）と $a_{0} / W$ (切欠き長さ比）が同義であることに依拠し ており，一般的ではないと考えられる.

このように材料力学的な整理では試験片サイズが大きくなるほど 板厚で正規化した限界荷重が低下した。この結果は寸法効果が顕在 化し, 結果を統一的に評価できなかったと解勫することができる. 次にこれらの試験結果を古典的な破壊力学パラメータで評価した場 合について次節以降で検討する.

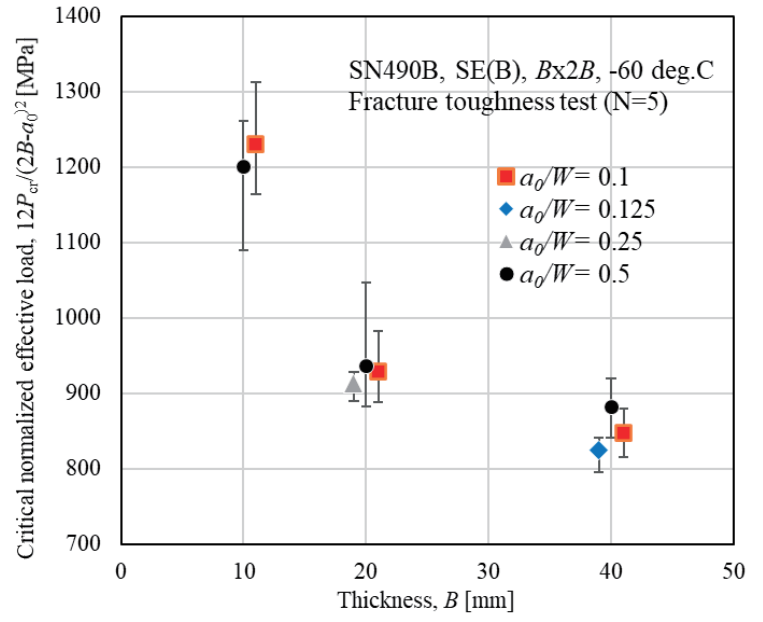

Fig. 10 Non-consistency of critical normalized effective force

\section{4 古典的破壊力学パラメータ, CTODによる整理}

2.2 節の試験結果を古典的破壊力学パラメータの一つである $\mathrm{CTOD}^{5)}$ を用いて整理する. 曲げ外力が加わった際のき裂先端の開口 量を指しており, 材料のねばり強さ, 寸なわち破壊力学における勒 性を表す指標である。 2.3 節の有効破壊荷重とは異なりき裂の存在 を前提としたパラメータであり，理想的には試験片寸法やき裂の深 さに依存しないとされている. CTOD 算定式 5,6)を式(5)〜(10)に示 す.ただし 2 章冒頭で述べた理由から，このパラメータを本研究で は quasi-CTOD と呼ぶこととする.

$$
\begin{gathered}
\delta_{\text {quasi }, \mathrm{cr}}=\frac{K_{\mathrm{cr}}{ }^{2}\left(1-v^{2}\right)}{m \sigma_{\mathrm{YS}} E}+\tau \cdot C_{V_{\mathrm{p}}} \cdot \frac{0.43\left(W-a_{0}\right) V_{\mathrm{p}}}{0.43\left(W-a_{0}\right)+a_{0}} \\
K=\frac{P_{\mathrm{cr}} \cdot S}{B \cdot W^{3 / 2}} Y
\end{gathered}
$$

$Y=3 \sqrt{\frac{a_{0}}{W}} \frac{1.99-\left(a_{0} / W\right)\left\{1-\left(a_{0} / W\right)\right\}\left\{2.15-3.93\left(a_{0} / W\right)+2.7\left(a_{0} / W\right)^{2}\right\}}{2\left\{1+2\left(a_{0} / W\right)\right\}\left\{1-\left(a_{0} / W\right)\right\}^{3 / 2}}$

$$
m=4.9-3.5\left(\frac{\sigma_{\mathrm{YS}}}{\sigma_{\mathrm{TS}}}\right)
$$

$$
\begin{gathered}
\tau=\left\{-1.4\left(\frac{\sigma_{\mathrm{YS}}}{\sigma_{\mathrm{TS}}}\right)^{2}+2.8\left(\frac{\sigma_{\mathrm{YS}}}{\sigma_{\mathrm{TS}}}\right)-0.35\right\}[0.8+0.2 \exp \{-0.019(B-25)\}] \\
C_{V_{p}}=-1.74\left\{\left(\frac{a_{0}}{W}\right)-0.45\right\}^{2}-1
\end{gathered}
$$

ここで， $\delta_{\text {quasi,cr }}$ は脆性破壊に達した際の $\delta_{\text {quasi }}$ である限界 quasi$\mathrm{CTOD}[\mathrm{mm}], K_{\mathrm{cr}}$ は限界応力拡大係数 $\left[\mathrm{N} / \mathrm{mm}^{3 / 2}\right], P_{\mathrm{cr}}$ は最大荷重 $[\mathrm{N}]$, $S$ は三点曲げ試験時のスパン長さ $[\mathrm{mm}], B$ は板厚 $[\mathrm{mm}], W$ は幅 $[\mathrm{mm}]$, $Y$ は形状補正係数, $v$ はポアソン比, $m$ は換算係数, $\sigma_{\mathrm{YS}}$ は降伏応力 $[\mathrm{MPa}], \sigma_{\mathrm{TS}}$ は引張応力 $[\mathrm{MPa}], E$ はヤング率 $[\mathrm{MPa}], \tau$ と $C_{V_{\mathrm{p}}}$ は塑性項 補正係数, $a_{0}$ は初期の切欠き長さ $[\mathrm{mm}], V_{\mathrm{p}}$ はクリップゲージ開口変 位の塑性成分 $[\mathrm{mm}], \delta_{\text {quasi,cr }}$ は限界 quasi-CTOD[mm]である。 $\sigma_{\mathrm{YS}}$, $\sigma_{\mathrm{TS}}$ については三点曲げ試験と同じ- $60^{\circ} \mathrm{C}$ 下で低温引張試験を実施 することで， $\sigma_{\mathrm{YS}}=420 \mathrm{MPa}, \sigma_{\mathrm{TS}}=746 \mathrm{MPa}$ が得られた。 $\nu, E$ につ いては今回の三点曲げ試験では $\nu=0.3, E=2.06 \times 10^{5} \mathrm{MPa}$ とした. 式(5)-(10)により算出した脆性破壊発生時の限界 quasi-CTOD の 結果を板厚 $B$ との関係として Fig. 11 に示す. また，同じ板厚を持 つ試験片の $\delta_{\text {quasi,cr }}$ の表示が重ならないように, 一部の試験片の板厚 の值を少しずらして表示している. 8 種類の試験片それぞれにおい 
て 5 本の試験片で三点曲げ試験を実施したので，ばらつき範囲をエ ラーバーで平均值をプロットとして示す.

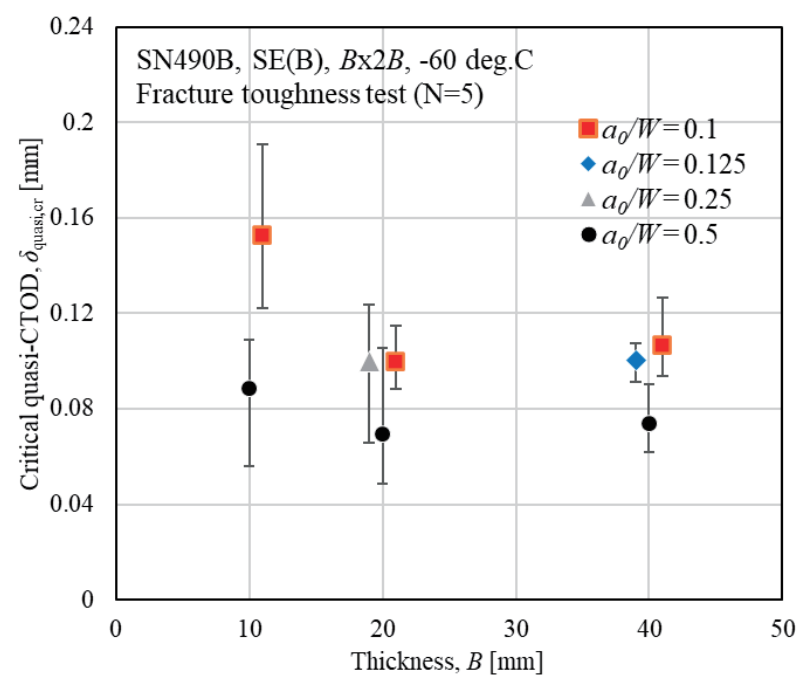

Fig. 11 Comparison of critical quasi-CTOD for thickness

Fig. 5 に示した同じ $a_{0} / W$ の值を持つ試験片の $\delta_{\text {quasi,cr }}$ を比較する と, 板厚が大きくなるほど $\delta_{\text {quasi,cr }}$ が減少している. また同じ板厚 である試験片の $\delta_{\text {quasi,cr }}$ を比較すると, 切欠きが深くなる場合でも $\delta_{\text {quasi,cr }}$ が減少している. 条件による $\delta_{\text {quasi,cr }}$ の平均值比は大きい場 合では約 2 倍程度とその差は小さくないことが分かる。つまり, quasi-CTOD で異なる三点曲げ試験片形状で破壊勒性を評価する 場合，寸法効果や切欠き形状の影響を受けると言える。また，影響 の要因はこれまでも破壊力学評価の中の短所として指摘されている 7)とおり，き裂先端が受ける塑性拘束（き裂先端近傍の塑性域が周 囲の弾性域に変形を拘束されること）の大小によるものと考えられ る. そのため, CTOD 試験で使用できる試験片の形状は限られた $a_{0} / W$ みであり, また評価対象である構造物と試験片の板厚は同 一であることを基本としている.

同じ $a_{0} / W$ であば $B=20 \mathrm{~mm}$ から $40 \mathrm{~mm}$ にかけて $\delta_{\text {quasi,cr }}$ の 值がおおよそ一定となるなど 2.3 節の有効破壊荷重と比べて改善し た部分も見られたが, quasi-CTOD も統一的な評価パラメータと みな寸には難しいと考えられた。

\section{3. ローカルアプローチ}

本章では，2 章で実施した三点曲げ試験を有限要素法（FEM ; Finite Element Method）解析によってモデル化し， ローカルアプ ローチによる試験片の破壊勒性の評価を行う。ローカルアプローチ の詳説を行ったのち, 本研究の三点曲げ試験にアプローチを適用し た評価結果を述べていく.

\section{1 ローカルアプローチとは}

本節では破壊力学の発展の歴史の中で構築されたローカルアプロ 一チとその代表的な指標であるワイブル応力について詳説する. 19 世紀から様々な破壊力学パラメータにより鋼の脆性破壊に対寸る抵 抗值である勒性が鋼材に対して表現されてきた.しかし脆性破壊は, 伝播停止しにくい性質から, 材料の構成要素の中で最も破壊しや寸 いものが一度破壊すれば材料全体の破壊に達するという最弱リンク
説 8)で説明される現象である．材料の勒性には，マイクロオーダー での鋼の組織不均一による勒性のばらつきと形状や負荷形態による 駆動力の変化により，本質的なばらつきが存在している.

勒性のばらつきを扱う手段として, Beremin は脆性破壊を確率的 事象として捉えるモデルを提案した ${ }^{9}$ ，構造体を 3 次元の微小な体 積要素に区切り，その体積要素 1 つ 1 つの破壊判定をすることで, 構造体全体の脆性破壊を評価するのがローカルアプローチである. Beremin は材料中のマイクロクラック分布を仮定しさらにワイブ ル確率関数を用いることで, 最弱リンク説に基づく材料全体の破壞 確率 $F$ を以下に示寸式(11)-(12)のように定義した。

$$
\begin{gathered}
F=1-\exp \left\{-\left(\frac{\sigma_{\mathrm{w}}}{\sigma_{\mathrm{u}}}\right)^{m}\right\} \\
\sigma_{\mathrm{w}}=\left\{\int_{V_{\mathrm{f}}} \sigma_{1}^{m} \frac{d V}{V_{0}}\right\}^{\frac{1}{m}}
\end{gathered}
$$

$m$ と $\sigma_{\mathrm{u}}$ は材料定数である. $m$ はワイブル形状パラメータとよばれ， 構造用鋼では 10～50 の值を取ることが多い 10)． $\sigma_{\mathrm{u}}$ は尺度パラメー タであり, 破壊確率が $63 \%$ 程度になるまでの值を示す. 式(12)に示 された $\sigma_{\mathrm{w}}$ がワイブル応力と呼ばれるものであり, 切欠き先端近傍の ように応力勾配を有する構造体での限界破壊応力を確率的観点から 代表值としたものである，特に，脆性破壊が発生する際のワイブル 応力を限界ワイブル応力と呼んでいる， $\sigma_{1}$ は破壊に寄与する有効応 力， $V_{0}$ はマイクロクラックを 1 つ含むような微小領域の基本体積で ある、また， $V_{\mathrm{f}}$ は構造体の中でも破壊に寄与寸る可能性のある領域 でありプロセスゾーンと呼ばれる.

1980 年代以降数值解析技術の発展に伴い, 構造体を微小要素に分 割したときに各々に負荷する局所的な応力ひずみ情報が取得できる ようになったため, ローカルアプローチが盛んになった． Bereminin ${ }^{9}$ モデルが提唱されて以来, Bordet ${ }^{11,12)}$ によるマイクロクラ ックの発生と進展の取り扱いの区分と塑性ひずみの関係を考慮した モデル, Bernauer 13)によるマイクロクラックの無力化モデル，応力 減少要素において破壊確率を無視寸るモデル 14,15), Lei16,17)によって 破壞が応力支配ではなく, 降伏後の応力増分であると考えたモデル など Beremin モデルから派生する様々な高精度予測モデルが提案 されている.

ローカルアプローチは，マクロな応答から得られる材料力学的な 指標や古典的な破壊力学パラメータによる評価とは異なり, 材料の 局所的な応力などを基に材料全体の脆性破壊を評価する方法である。 そのため, 理想的には材料の形状などに依存せず材料固有の值で破 壊勒性を評価できることが期待される。ローカルアプローチを行う には局所的な応力場の情報などが必要となるが，汎用 FEM ソフト ウェアを用いて非線形大変形弾塑性解析を実施し, 試験片が破壞に 至るまでの局所的な応力場やひずみ場などの情報を比較的簡単に取 得する．取得した局所分布の情報をベースにこれまで提案されてき た様々な評価モデルを今回の各鋼板の三点曲げ試験に対して適用し， どのモデルが材料の破壞勒性を統一的に評価できるかを比較する.

\section{2 有限要素法解析}

3 次元弾塑性有限要素法解析に必要な材料特性として, 弾性係数 については等方性を仮定した．また，応力ひずみ関係については，

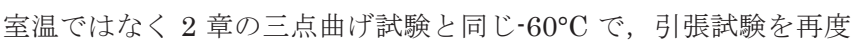
実施して決定した。引張試験の結果を Fig. 12 に示す. 


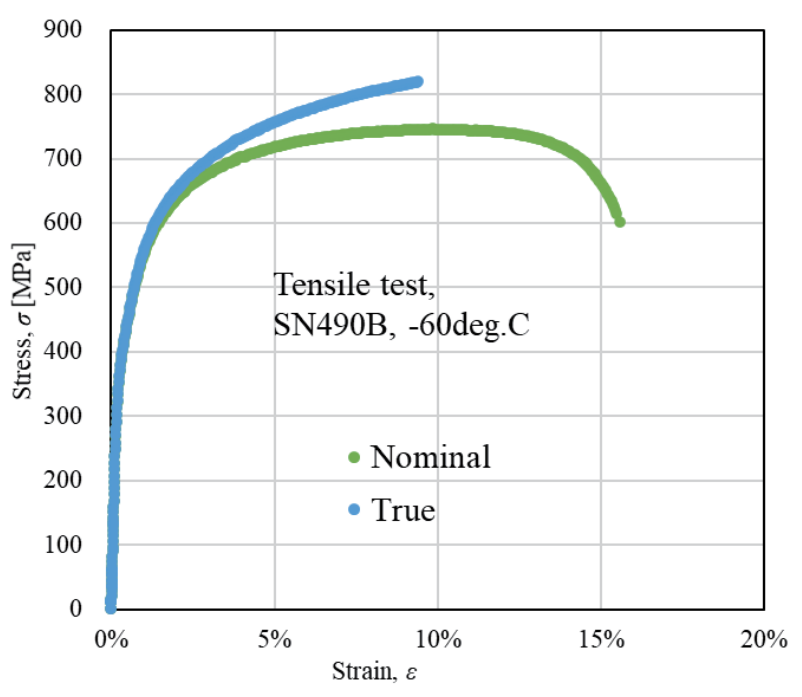

Fig. 12 Tensile test in low temperature

公称応力ー公称ひずみ曲線を基に真応力一真ひずみ曲線に変換し たのち, 真ひずみから弾性ひずみ成分を引いた塑性ひずみ $\left(\varepsilon_{\mathrm{p}}\right)$ と真 応力の関係を $n$ 乗硬化則によって近似した. 近似式には式(13)に示す Swiftの式を利用した。

$$
\sigma_{\mathrm{t}}=\sigma_{\text {true }, \mathrm{YS}}\left(1+\frac{\varepsilon_{\mathrm{p}}}{\alpha}\right)^{n}
$$

ここで, $\sigma_{\mathrm{true}, \mathrm{YS}}$ は降伏応力, $n$ はひずみ硬化指数, $\alpha$ は定数である. 最小二乗法を用いて近似解を計算した結果， $\sigma_{\text {true,YS }}=419.5 \mathrm{MPa}$, $n=0.149, \alpha=0.00092$ が得られた. Swift の式のフィッティングから 得られた塑性ひずみと真応力の関係を相当塑性ひずみ, 相当応力に 読み替え, FEM 解析の際の応力ひずみ関係として用いた。

FEM 解析の際の要素分割については, 後述するワイブル応力の 計算の際に要素分割の影響が出ないように, 切欠き先端の近傍の要 素分割は 8 種類の試験片の FEM 解析で統一寸ることとした，板厚 方向の垂直面において, 切欠き先端から半径 $500 \mu \mathrm{m}$ の範囲におい ては要素を $30 \mu \mathrm{m}$ の長さに要素分割することとした. 切欠き先端の 周辺の要素分割を切欠き長さ比 $a_{0} / W=0.5$, 板厚 $B=40 \mathrm{~mm}$ の試験片 を例に Fig. 13 に示寸. 使用した要素は 8 節点 6 面体アイソパラメ トリック要素, 使用したソフトウェアは Abaqus2018 である.

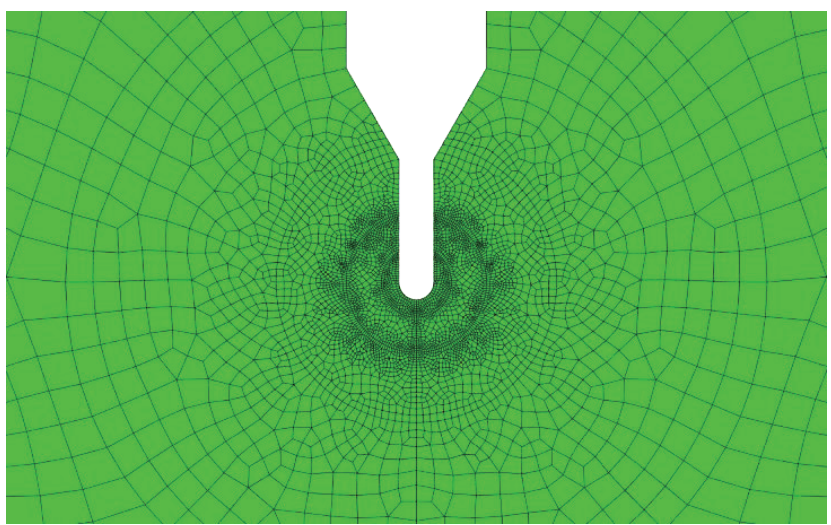

Fig. 13 Division of element in FE analysis

\section{3 評価試行モデル}

ローカルアプローチによる破壊評価モデルの一つに，脆性破壊発 生時の最大主応力分布を見たときの最大值を限界破壊応力とするこ とがある、三点曲げ試験の場合には，最大主応力は板厚中心におけ るき裂先端の近傍で最大值を取ることが多い。しかし，脆性破壊時 の最大主応力の最大值が仮に同じ值を取ったとしても，き裂先端の 近傍の応力分布が大きく異なることがある．破壊が確率事象である ことから, 応力分布が異なれば破壊確率も異なる，点応力により決 定された限界破壊応力による評価ではき裂先端の近傍の応力分布を 考慮できない。本研究では最弱リンク説 ${ }^{8)}$ に基づいた, Beremin モ デル 9), Bordet モデル 11,12)に加え, 最近の日本の鋼材を用いて塑性 ひずみの影響を表す関数形を脆性破壊起点位置との整合性をもって 決定した Yoshizu モデル 18)を追加し，それぞれの定義による限界ワ イブル応力を三点曲げ試験の材料の破壊勒性の評価モデルに用いる こととした.

Beremin モデル, Bordet モデル, Yoshizu モデルそれぞれにおけ るワイブル応力 $\sigma_{\mathrm{w}}$ の計算方法と式番号を以下の Table 3 に示す. 式 （15）におけるßはマイクロクラックの発生確率の塑性ひずみへの依 存性を表す指数であり, Yoshizu の研究では $\beta=1.5$ が最適であると 求められた. 本研究もYoshizu の研究も実用鋼を対象としているこ とから，今回の計算でも $\beta$ の值は 1.5 とした。式(12)，(14)，(15)の 導出過程は各モデルの原著論文 $8,10,11,18)$ に詳述されており, 特に Beremin モデルの導出については日本語論文で南 7)が詳述している. いずれのモデルも微小体積の破壊確率を定義して全体の破壞確率に ついて最弱リンク機構を考慮して式変形したものである.

\begin{tabular}{c|c}
\multicolumn{2}{c}{ Table 3 Formulae to calculate Weibull stress } \\
model & formulae \\
\hline Beremin $^{9)}$ & $\sigma_{\mathrm{w}}=\left\{\int_{V_{\mathrm{f}}} \sigma_{1}^{m} \frac{d V}{V_{0}}\right\}^{\frac{1}{m}}$ \\
Bordet $^{11,12)}$ & $\sigma_{\mathrm{w}}=\left\{\int_{V_{\mathrm{f}}}\left(\int_{0}^{\varepsilon_{\mathrm{p}}} \sigma_{1}^{m} d \varepsilon_{\mathrm{p}}\right) \frac{d V}{V_{0}}\right\}^{\frac{1}{m}}$ \\
Yoshizu $^{18)}$ & $\sigma_{\mathrm{w}}=\left\{\int_{V_{\mathrm{f}}}\left(\int_{0}^{\varepsilon_{\mathrm{p}}} \varepsilon_{\mathrm{P}}^{\beta-1} \sigma_{1}^{m} d \varepsilon_{\mathrm{p}}\right) \frac{d V}{V_{0}}\right\}^{\frac{1}{m}}$
\end{tabular}

$\sigma_{1}$ は最大主応力 $[\mathrm{MPa}], \varepsilon_{\mathrm{p}}$ は相当塑性ひずみ $[\%]$ である. $\sigma_{1}$ は本来， 破壞に寄与寸る有効応力だが，今回はその有効応力を最大主応力と した． $V_{\mathrm{f}}$ は破壊に寄与寸る可能性のあるき裂先端近傍の領域（プロ セスゾーン）であり, Fig. 14 では切欠き長さ比 $a_{0} / W=0.5$, 板厚 $B$ $=40 \mathrm{~mm}$ の試験片を例にプロセスゾーンを赤色で示してある. $V_{0}$ は 基本体積であり, 今回は計算の簡素化のために $1 \mathrm{~mm}^{3}$ とした.

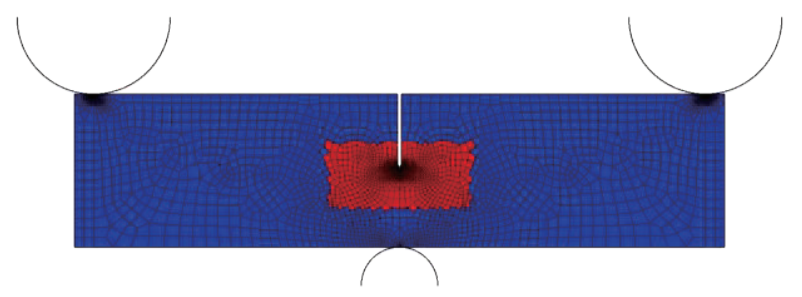

Fig. 14 Process zone in the test specimen 
FEM 解析において得られる各要素の体積, 最大主応力, 相当塑性 ひずみを式(12)，(14)，(15）の計算に用いた。式(12)，(14)，(15）に おける体積積分は各要素の体積を微小体積とみなした. また, FEM 解析において自動的に生成される各中間タイムステップにおいて quasi-CTOD とワイブル応力を算出しておき, 第 2 章に示した実験 で得られた限界 quasi-CTOD に隣接する 2 点のタイムステップの 情報を用いて直線補間することで限界ワイブル応力を算出した。

式(12)，(14)，(15）に基づき Beremin モデル, Bordet モデル, Yoshizu モデルの各モデルで 8 種類の試験片の限界ワイブル応力を 計算した結果を板厚 $B$ との関係として Fig. 15 に示す. 各モデルに おけるmの值は, Minami ら 10)が示したmの最尤推定法手順を使い, 近似的に Beremin: $m=21$, Bordet: $m=31$, Yoshizu: $m=31$ とした. 図の縦軸が限界ワイブル応力 $\sigma_{\mathrm{w}, \mathrm{cr}}$, 横軸が試験片の板厚 $B$ を表す. 8 種類それぞれで 5 本の試験片の限界ワイブル応力を算出したのちに, その 5 本の平均值をグラフにプロットした． 2 章で述べた限界荷重 や限界 quasi-CTOD と比較して, いずれのモデルの限界ワイブル応 力も統一的に評価できていると言える. 試験片サイズの増大による き裂先端位置における高応力領域の体積増加や, 切欠き長さ比の増 大による塑性拘束の増加に伴う応力の絶対值増加が, Beremin モデ ルの評価には少しばらつきを与えている. しかし，相当塑性ひずみ (試験片サイズあるいは切欠き長さ比が小さいほじ, 塑性拘束も小 さく塑性変形しやすい）を考慮した Bordet モデル, Yoshizu モデル はそのばらつきが改善されている. また, Bordetモデルと Yoshizu モデルは Beremin モデルと比べて $\sigma_{\mathrm{w}, \mathrm{cr}}$ の值が小さい傾向がある.い ずれのモデルも, 式(12), (14), (15) から明らかなように, 今回 $100 \%$ 以下，つまり 1 以下の值を取っていることが多い相当塑性ひずみ $\varepsilon_{\mathrm{p}}$ が項に加わっているためであると考えられる。

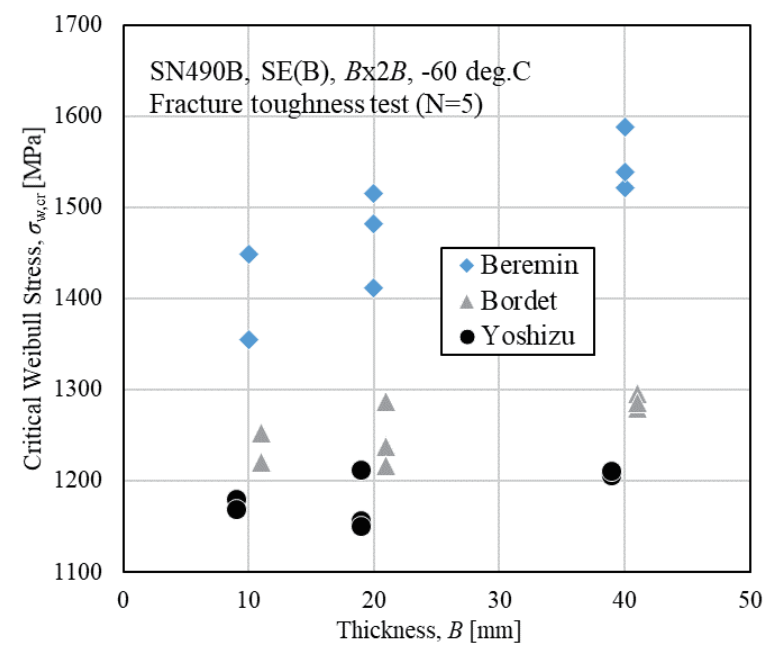

Fig. 15 Comparison of critical Weibull stress among the models

本研究の目的は材料の外形寸法や切欠き長さ比などに影響を受け ず材料の破壞勒性を統一的に評価できる指標を導出することであり， 限界条件は一定の值を示寸ことが望ましい. そこで, Fig. 15 に示し た 3 つのモデルそれぞれについて, 8 種類の試験片の限界ワイブル 応力の標準偏差を比較する. 各モデルの標準偏差を Fig. 16 に示す. 左の縦軸が各モデルにおける限界ワイブル応力の標準偏差の值であ
り，棒グラフで示してある．また，右の縦軸は標準偏差をモデルの 限界ワイブル応力の平均值で除した值（\%表示）であり，折れ線グ ラフで示してある.いずれのモデルも平均的な值に対してばらつき がかなり小さいことが右の縦軸から読み取れるが, Yoshizu モデル は特にばらつきが少なく, 統一的に破壊勒性を評価できる指標であ ると考えられる。

元々Beremin モデルは, 材料の微小部分の破壊において, 元から マイクロクラックが一定して存在すると仮定したモデルである.

Bordet モデルと Yoshizu モデルは, 双方ともマイクロクラックは当 初から存在するものではなく, 負荷される塑性ひずみ量に応じて生 成するとしたモデルであり，実際の鋼材に初期クラックがほとんど 存在しないことを考慮すれば実現象に忠実であると言えよう．Fig. 15, Fig. 16 の結果から，完全に統一的に評価できるとは言い難い が, Beremin モデルの評価が Bordet モデルや Yoshizu モデルによ って大きく改善されたことが読み取れる. 寸なわち，局所的な材料 の破壊に着目寸る際には応力に加えて相当塑性ひずみが寄与するマ イクロクラック発生を考慮する妥当性が確認されたと言える.

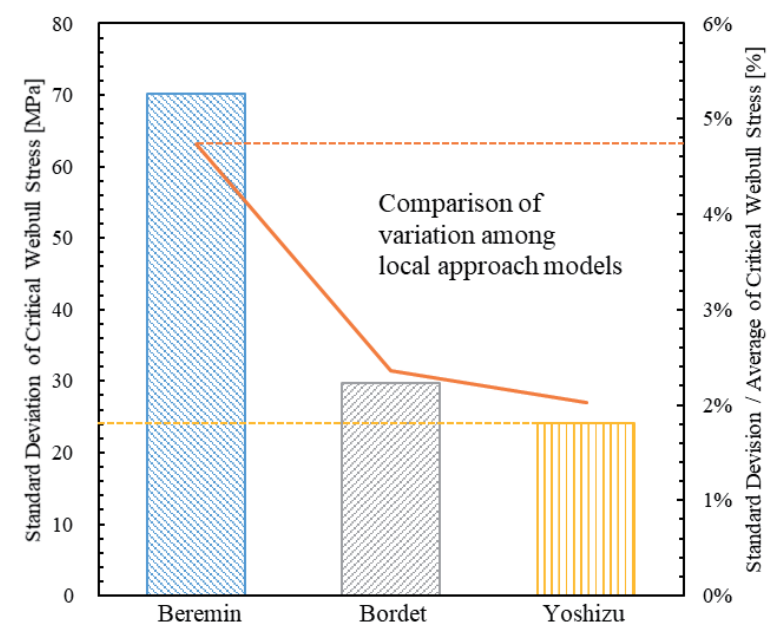

Fig. 16 Comparison of variation among local approach models

材料破壊をサイズや切欠きなどに依存せず統一的に評価するには 実験から巨視的に得られるマクロ応答だけでなく, き裂先端などの 破壊が発生する局所的な領域の物理的情報まで考慮することが重要 であると, 材料力学, 古典的破壊力学, ローカルアプローチによる 整理の比較から考えられる. また, 物理情報を利用した評価モデル を構築する際には, 脆性破壊に至るまでのき裂発生から進展などの ように実際の物理物象と照らし合わせることが重要であると言える。

Fig. 2 に示寸柱梁溶接接合部の破壊実験で見られた寸法効果と Fig. 10 や Fig. 11 に示寸今般実施した試験片における寸法効果には 相似性が認められ，定性的には脆性破壊の寸法効果が構造物の破壊 性状における寸法効果の一部をなしていることを推定できる.

\section{4. 結論}

サイズや切欠き長さ比の異なる 8 種類の試験片に対して三点曲げ 試験を実施した。試験結果から, 脆性破壊特性に及ぼす試験片の寸 
法効果の評価, 脆性破壊特性をサイズや切欠き長さ比に依らず統一 的な評価が可能であるかの検討を行った，各手法における評価や検 討の結果は以下の通りである.

・材料力学的な整理 : 試験片サイズが大きくなるほど板厚で正規化 した限界荷重が低下した。これは寸法効果が顕在化した結果である と考えられ，統一的な評価は難しいことを意味する．

・古典的な破壊力学による整理 : 試験片サイズ (寸法効果) の影響 は材料力学的な整理に比べると小さくなったが, 切欠き長さ比が大 きくなるほど限界 quasi-CTOD が減少した. 理由としては, き裂先 端が受ける塑性拘束の大小が試験片サイズや切欠き長さ比の影響を 受けたためであると考えられた。つまり古典的な破壊力学として限 界 quasi-CTOD を用いても統一的な評価は難しかった。

・ローカルアプローチによる整理 : 上記の限界荷重, 限界 quasiCTOD と比較して寸法効果の影響をあまり受けなかった。つまり, き裂先端の局所的な応力場が, 試験片サイズに依らず脆性破壊の限 界条件を統一的に説明できているものと考えられる. 特に Yoshizu モデルでは, Bordet モデルと同様マイクロクラック発生に寄与する ひずみ場の影響も考慮することで, 更に統一的な評価を行うことが できた.

ローカルアプローチによる評価を行う際には 3 次元弾塑性有限要 素法解析を実施した。板厚が厚くなった, あるいはき裂が長くなっ た場合に単純なスケール則から結果が冕脱する現象である寸法効果 が発生する理由は, き裂先端位置における高応力領域の体積が増加 することと応力高揚部分の絶対值が上昇することであると解析によ り分かった.

今後, 柱梁接合部が繰り返し載荷を受けた場合の脆性破断限界に おける寸法効果の全容を明らかにする上で，脆性破壊部分について は，Yoshizu モデルを使用寸れば良いと言える．残る主要な寸法効 果の構成要素として考えられる延性き裂発生・進展特性および溶接 残留応力特性については, 著者らによって既に検討を始めているた め注 1 , 注 2), 有限要素法において全てのファクターを考慮可能とした モデルを作成するなどにより, それぞれの寄与割合を検討したいと 考えている. さらに, 実用的な側面を考慮すれば縮小試験を実施す る際の換算式の提案などにつなげていく必要がある.

\section{謝辞}

本研究は, 東京工業大学 - 実大加力実験工学共同研究講座 (笠井 和彦研究室）とその構造部材破壊現象検討委員会 (和田章委員長) による企画, および講座支援者であるオイレス工業, KYB, 昭和電 線ケーブルシステム, 日本鉄鋼連盟, ブリヂストン（五十音順）の 助成により行われました。また，本研究はJSPS 科研費（コード： JP19H00802）の助成も受け，一般社団法人日本鉄鋼連盟殿から鋼 構造研究 - 教育助成事業の対象事業として推進し, 実験の遂行は信 州大学大学院合田貴紀氏, 東京大学大学院岩田裕真氏と共同実施し ました。ここに記して関係各位に謝意を表します。

\section{参考文献}

1) British Standard: BS $7910: 2019$, Guide to methods for assessing the acceptability of flaws in metallic structures, 2019

2) The Japan Welding Engineering Society: WES2805-2011, Method of Assessment for Flaws in Fusion Welded Joints with Respect to Brittle
Fracture and Fatigue Crack Growth, 2011

日本溶接協会 : WES2805-2011, 溶接継手のぜい性破壊発生及び疲労亀裂 進展に対する欠陥の評価方法, 2011

3) Nakagomi, T., Yamada, T., Murai, M., Matoba, K., Aida, K. Experimental study on the effects of beam-end details for non-scallop method on deformation capacities of beam-to-column welded joints, Journal of Structural and Construction Engineering (Transactions of AIJ), Vol. 66, No. 546, pp. 121-128, 2001.8

中込忠男, 山田丈富, 村井正敏, 的場耕, 會田和広：ノンスカラップ工法 における梁端ディテールが柱梁溶接接合部の変形能力に及ぼす影響に関す る実験的研究, 日本建築学会構造系論文集, 第 66 巻, 第 546 号, pp. 121128, 2001.8

4) Nakagomi, T., Kaneko, H., Tsutumi, S., Masuda, K., Makishima, J., and Horiba, R.: Study of influence beam-end joint details with field welding on deformation capacity of pre-build-up $\mathrm{H}$-shape beam-tocolumn joint, Journal of Structural and Construction Engineering (Transactions of AIJ), Vol. 82, No. 739, pp. 1497-1506, 2017.9 中込忠男, 金子洋文, 堤成一郎, 増田開, 巻島淳, 堀場亮佑 : 現場溶接型 梁端仕ロディテールが先組みビルト $\mathrm{H}$ 梁を用いた柱梁溶接接合部の変形 能力に及ぼす影響に関する実験的研究, 日本建築学会構造系論文集, 第 82 巻, 第 739 号, pp. 1497-1506, 2017.9

5) International Organization for Standardization: ISO15653:2016, Metallic materials - Unified method of test for the determination of quasistatic fracture toughness, 2016

6) Kawabata, T. et al: Proposal for a new CTOD calculation formula, Engineering Fracture Mechanics, Vol. 159, pp. 16-34, 2016

7) Minami, F.: Fracture Assessment Method Using the Weibull StressPart I, Japan Welding Society, Vol. 75, No. 5, pp. 416-446, 2006 南二三吉 : ワイブル応力を用いた破壊評価手法一Part I, 溶接学会誌, 第 75 巻, 第 5 号, pp. 416-446, 2006

8) Weibull, W.: A statistical theory of the strength of materials, Ing. Vetenskaps Akad. Handl, Vol. 151, 1939

9) Beremin, F. M.: A local criterion for cleavage fracture of a nuclear pressure vessel steel, Metallurgical Transactions A, Vol. 14, pp. 22772287, 1983

10) Minami, F. et al: Method of constraint loss correction of CTOD fracture toughness for fracture assessment of steel components, Engineering Fracture Mechanics, Vol. 73, No. 14, pp. 1996-2020, 2006

11) Bordet, S. R.: A new statistical local criterion for cleavage fracture in steel. Part I: model presentation, Engineering Fracture Mechanics, Vol. 72, No. 3, pp. 435-452, 2005

12) Bordet, S. R.: A new statistical local criterion for cleavage fracture in steel. Part II: application to an offshore structural steel, Engineering Fracture Mechanics, Vol. 72, No. 3, pp. 453-474, 2005

13) Bernauer, G. et al: Modifications of the Beremin model for cleavage fracture in the transition region of a ferritic steel, Engineering Fracture Mechanics, Vol. 64, pp. 305-325, 1999

14) Takashima, Y., Ohata, M., and Minami, F.: Weibull Stress Approach to Correlation between Charpy Impact Energy and CTOD Fracture Toughness, Proceedings of 9th European Mechanics of Materials Conference, pp. 81-86, 2006

15) Kawabata, T., Ohata, M., Minami, F.: Critical Condition of Ductile Crack Extension and Its Critical Condition of Subsequent Brittle Fracture for high Strength Steel, Journal of the Japan society of naval architects and ocean engineers, Vol. 5, pp. 235-243, 2007 川畑友弥，大畑充，南二三吉: 高強度鋼における延性き裂の進展とその後の 脆性破壊限界条件に関寸る検討, 日本船舶海洋工学会論文集, 第 5 巻, pp. 235-243, 2007

16) Lei, W. S.: A cumulative failure probability model for cleavage fracture in ferritic steels, Mechanics of Materials, Vol. 93, pp. 184-198, 2016

17) Lei, W. S.: A discussion of "An engineering methodology for constraint corrections of elastic-plastic fracture toughness- Part II: Effects of specimen geometry and plastic strain on cleavage fracture predictions", Engineering Fracture Mechanics, Vol. 178, pp. 527-534, 2017

18) Yoshizu, S.: Probabilistic Fracture Mechanics Analysis on the 
Scatter of Critical CTOD, Procedia Materials Science, Vol. 3, pp. 14471452,2014

注

注 1) Kishiki, S., Kawabata, T., Nakagomi, T., Murata, T., Aoyagi, S., and Kasai, K.: Experimental Evaluation of Scale Effect on Plastic Deformation Capacity of Steel Beam-End Connection, 17th World Conference on Earthquake Engineering, 17WCEE, proceedings to be published.

注 2) Kawabata, T., Nakagomi, T., Kishiki, S., Aoyagi, S., Murata, Y., and Kasai, K.: Fracture mechanics investigation on brittle fracture behavior under cyclic load in steel beam-end connections with proportional shapes, 17th World Conference on Earthquake Engineering, 17WCEE, proceedings to be published. 


\title{
ISSUES IN USING REDUCED-SIZE SPECIMEN FOR BRITTLE FRACTURE EVALUATION OF BEAM-TO-COLUMN STEEL CONNECTIONS
}

Geometric size effect on brittle fracture properties

\author{
Naoya OIE ${ }^{* 1}$, Tomoya KAWABATA ${ }^{* 2}$, Shoichi KISHIKI*3 \\ and Tadao NAKAGOMI*4
}

\author{
${ }^{*}$ Grad. Student, Dept. of Systems Innovation, Faculty of Engineering, the University of Tokyo, B.Eng. \\ *2 Prof., Dept. of Systems Innovation, Faculty of Engineering, the University of Tokyo, Dr.Eng \\ * 3 Prof., Laboratory for Future Interdisciplinary Research of Science and Technology, Institute of Innovative Research, Tokyo Institute of Technology, Dr.Eng \\ ${ }^{* 4}$ Specially Appointed Prof., Dept. of Architecture, Faculty of Engineering, Shinshu University, Dr.Eng.
}

In steel structures, brittle fracture must be considered first as the final form of failure in seismic design. Brittle fracture is a critical failure phenomenon that must be avoided because the structure loses its function instantaneously. In recent years, as the size of buildings and numbers of the layers have increased, the thickness of framing components has also increased, making brittle fracture more likely to occur. The simplest way to evaluate the fracture resistance is to conduct experiments on full scale structures, however this is often difficult in practice, so the performance is usually evaluated on the reduced scale model. Fracture mode of structures exhibits both ductile and brittle manner thus the scale effect must be considered in both viewpoints. Moreover, the influence of residual stress distribution at welds and weld deformation on the results may vary depending on the dimensions of the model.

In this study, aiming to extract the relationship between geometrical shape (size) and brittle fracture properties, the scale effect on brittle fracture initiation properties was evaluated using the proportionally sized specimens with 4:2:1 geometry. The feasibility of employing uniform parameters is also verified by means of a fracture evaluation index based on the latest fracture mechanics.

Three-point bending tests were conducted on eight types of specimens with different sizes and notch depths. It was confirmed that brittle fracture occurred in all specimens (a total of 40 specimens) from the measurement of the forceclip gage opening displacement curve and the observation of the specimen fracture surface by scanning electron microscope (SEM).

Firstly, the fracture forces normalized by the thickness of each specimen was employed based on the idea of critical bending stress, assuming that the specimen is a simple beam member. However, the interpretation by this index showed significant scale effect, where the thicker the lower. Secondly, fracture parameter, crack tip opening displacement (CTOD) was used as an index. By using CTOD, the effect of the absolute depth of the notches can be considered, however, the scale effect was remained. Finally, by obtaining stress-strain information during deformation over the specimen details through 3D FEM analysis, a local approach (Weibull stress criterion), which can faithfully describe the micromechanism of brittle fracture, was employed for the interpretation. A modified Weibull stress model to coincide the real microcrack formation was adopted to eliminate the scale effect and to interpret the fracture critical conditions with a single parameter. This modified Weibull stress criterion considers the contribution of plastic strain to microcrack formation. In sum, the scale effect appeared in simple normalized fracture force index and CTOD was due to the increase in the absolute value of the stress elevation by the increase of constraint at the crack tip and the increase in the volume of the high stress region. 